\title{
Methylophaga marina gen. nov., sp. nov. and Methylophaga thalassica sp. nov., Marine Methylotrophs
}

\author{
MONIQUE JANVIER, ${ }^{1}$ CLAUDE FREHEL,${ }^{2}$ FRANCINE GRIMONT ${ }^{3}$ AND FRANCIS GASSER ${ }^{1 *}$ \\ Unité de Physiologie Cellulaire, Département de Biochimie et Génétique Moléculaire ; Unité de Microscopie \\ Electronique, Département de Biologie Moléculaire ${ }^{2}$; and Unité des Entérobactéries, Institut National de la \\ Santé et de la Recherche Médicale Unité 199, Département de Bactériologie et Mycologie, ${ }^{3}$ Institut Pasteur, F-75724 \\ Paris Cedex 15, France
}

\begin{abstract}
After enrichment in a medium containing seawater and methanol, 42 methylotrophic strains were isolated. All of these strains were gram-negative, strictly aerobic, motile, rod-shaped organisms that required vitamin $B_{12}$. None grew on methane or on complex nutrient media supplemented or not supplemented with $\mathrm{NaCl}$. All but 2 strains grew on methanol, methylamine, and fructose, 17 strains grew on dimethylamine, and 10 strains grew on trimethylamine. Fructose was the only multicarbon compound tested that was used as a growth substrate. All 11 strains tested used the ribulose monophosphate pathway of carbon assimilation. Depending on the strain, methylamine was oxidized either through a methylamine dehydrogenase or through a methylglutamate dehydrogenase. The mean guanine-plus-cytosine content of 33 strains was 43 mol\%. Based on deoxyribonucleic acid-deoxyribonucleic acid hybridization, two related groups were identified among 11 strains examined. We propose a new genus, Methylophaga, with two species, Methylophaga marina (type species) and Methylophaga thalassica. There was no significant deoxyribonucleic acid hybridization between Methylophaga and the terrestrial obligate methanol utilizers tested. The type strains of $M$. marina and $M$. thalassica are strains ATCC 35842 (= NCMB 2244) and ATCC 33146 (= NCMB 2163), respectively.
\end{abstract}

A number of terrestrial strains of gram-negative, obligate or restricted-facultative methylotrophs which use the ribulose monophosphate pathway (RuMP) for carbon source utilization and are unable to utilize methane have been described previously (for a review, see reference 2). Some of these strains did not receive generic designations. Others have been referred to as Methylomonas $(1,14,26,30,34,46$, 50), "Methylophilus" (33, 51), or Methylobacillus (59). Recently, the name Methylomonas was revived for a category of strict methane utilizers $(28,56)$. For the category of bacteria defined above, only the genus Methylobacillus is mentioned on the Approved Lists of Bacterial Names (48), with one species, Methylobacillus glycogenes. These terrestrial methylotrophs are characterized by deoxyribonucleic acid (DNA) guanine-plus-cytosine contents which range from 50 to $53 \mathrm{~mol} \%$. A DNA relatedness study (10) of terrestrial methylotrophs identified two groups, corresponding to Methylobacillus glycogenes and "Methylophilus methylotrophus."

The taxonomic position of gram-negative, marine methylotrophs that are unable to utilize methane is even more confused. The strains described in 1978 by Yamamoto et al. (58) were later assigned to two different genera on the basis of the ability of the strains to utilize fructose as a growth substrate. The fructose-utilizing strains were designated "Alteromonas thalassomethanolica," whereas the strains that were claimed to be unable to utilize fructose were designated "Methylomonas thalassica"' (57).

Recently, Strand and Listrom (49) described a similar marine obligate methylotroph (strain FMD) which utilizes methanol through the RuMP pathway. Strand and Listrom did not name their strain, but suggested that it might belong to the genus "Methylophilus." The guanine-plus-cytosine content of the DNA of marine methylotrophs is about 45 mol\% $(49,57)$.

\footnotetext{
* Corresponding author.
}

The purposes of the present work were to (i) characterize phenotypically 42 new marine methylotrophic isolates, (ii) delineate species by DNA-DNA hybridization, and (iii) compare our strains with available marine or terrestrial methylotrophic strains representative of previously published studies. The outcome of this study was the description and designation of a new genus, Methylophaga, with two new species, Methylophaga marina and Methylophaga thalassica.

\section{MATERIALS AND METHODS}

Bacterial strains. The newly isolated strains used for taxonomic characterization are listed in Table 1. The following strains were received from the American Type Culture Collection: Methylobacillus glycogenes ATCC $29475^{\mathrm{T}}(\mathrm{T}=$ type strain); "Alteromonas thalassomethanolica" ATCC 33145; and "Methylomonas thalassica" ATCC $33146^{\mathrm{T}}$. The following strains were received from the National Collection of Industrial and Marine Bacteria: "Methylomonas thalassica" NCMB $2163^{\mathrm{T}}$ (= ATCC $33146^{\mathrm{T}}$ ); " Methylomonas thalassica" NCMB 2162; Alteromonas macleodii NCMB $1963^{\mathrm{T}}$; and "Methylophilus methylotrophus" NCIB 10515. Methylotrophic strains AM1 and M27, Pseudomonas sp. strain C, and "Methylomonas methanolica" were received from I. Goldberg, Hebrew University, Hadassah Medical School, Jerusalem, Israel. Pseudomonas fluorescens CIP 7325 and Escherichia coli K-12 CIP 54117 were obtained from the Collection de l'Institut Pasteur, Paris, France.

Media. For enrichments and isolations, natural seawater was used as a mineral base. The seawater was kept in the dark for 2 weeks, filtered through $0.45-\mu \mathrm{m}$ membranes (Millipore Corp., Bedford, Mass.), and autoclaved for 30 min at $120^{\circ} \mathrm{C}$. The final seawater medium contained (per liter) $0.14 \mathrm{~g}$ of $\mathrm{KH}_{2} \mathrm{PO}_{4}, 2 \mathrm{~g}$ of $\mathrm{NH}_{4} \mathrm{Cl}, 60 \mathrm{mg}$ of ferric ammonium citrate, and $2 \mathrm{~g}$ of Bis-Tris (Sigma Chemical Co., St. Louis, Mo.). These ingredients were added separately as a $50 \times$ stock mixture (solution $\mathrm{A}$ ) adjusted to $\mathrm{pH} 7.4$ and autoclaved at $120^{\circ} \mathrm{C}$. Methanol was added to a concentration 
TABLE 1. Utilization of fructose and methylated amines by marine methylotrophic bacteria

\begin{tabular}{|c|c|c|c|c|c|c|}
\hline \multirow{2}{*}{ Strain $^{a}$} & \multicolumn{4}{|c|}{ Utilization of: } & \multicolumn{2}{|c|}{$\begin{array}{l}\text { Enzymes of monomethylamine } \\
\text { oxidation }\end{array}$} \\
\hline & Fructose & Monomethylamine & Dimethylamine & Trimethylamine & $\begin{array}{l}\text { Methylamine } \\
\text { dehydrogenase }\end{array}$ & $\begin{array}{l}\mathrm{N} \text {-Methylglutamate } \\
\text { dehydrogenase }\end{array}$ \\
\hline \multicolumn{7}{|l|}{ Methylophaga thalassica } \\
\hline $\begin{array}{l}\text { "Alteromonas thalassomethanolica" } \\
\text { ATCC } 33145\end{array}$ & + & + & + & + & + & - \\
\hline $\begin{array}{l}\text { "Methylomonas thalassica" ATCC } \\
33146^{T}\end{array}$ & $++^{b}$ & + & - & - & - & $+(\mathrm{W})^{c}$ \\
\hline $\begin{array}{l}\text { "Methylomonas thalassica" NCMB } \\
2162\end{array}$ & - & + & + & + & - & + \\
\hline New strain 310 & + & + & + & + & - & + \\
\hline New strain 150 & + & + & + & + & - & + \\
\hline New strain $2 b$ & + & + & + & - & - & + \\
\hline New strain 1d & + & + & + & + & - & + \\
\hline \multicolumn{7}{|l|}{ Methylophaga marina } \\
\hline $222^{\mathrm{T}}$ & + & + & - & - & + & - \\
\hline $92 \mathrm{~b}$ & + & + & - & - & - & + \\
\hline 81 & + & + & - & - & + & - \\
\hline 290 & + & + & - & - & - & + \\
\hline 232 & + & + & - & - & + & - \\
\hline 312 & + & + & - & - & + & - \\
\hline 173 & + & + & + & - & + & - \\
\hline
\end{tabular}

${ }^{a}$ ATCC, American Type Culture Collection; NCMB, National Collection of Marine Bacteria.

${ }^{b}$ See text.

"(W), Weak reaction.

of $0.3 \%(\mathrm{vol} / \mathrm{vol})$. For solid media, $16 \mathrm{~g}$ of Bacto-Agar (Difco Laboratories, Detroit, Mich.) per liter was added. Subcultures were made in artificial seawater (ASW) medium composed of ASW supplemented with solution $A$ and vitamin $\mathrm{B}_{12}(1 \mu \mathrm{g} /$ liter). ASW contained (per liter) $24 \mathrm{~g}$ of $\mathrm{NaCl}, 3 \mathrm{~g}$ of $\mathrm{MgCl}_{2} \cdot 6 \mathrm{H}_{2} \mathrm{O}, 2 \mathrm{~g}$ of $\mathrm{MgSO}_{4} \cdot 7 \mathrm{H}_{2} \mathrm{O}, 0.5 \mathrm{~g}$ of $\mathrm{KCl}, 1 \mathrm{~g}$ of $\mathrm{CaCl}_{2} \cdot 2 \mathrm{H}_{2} \mathrm{O}$, and $0.5 \mathrm{~g}$ of Bis-Tris. The trace element solution of Pfennig (36) was added to a concentration of $1 \%$ ( $\mathrm{vol} / \mathrm{vol}$ ). The final pH was 7.4. For solid media, a sterile solution of Bacto-Agar (Difco) in water ( $32 \mathrm{~g} / \mathrm{liter}$ ) was added to an equal volume of double-strength ASW medium.

Growth substrates and growth conditions. All of the growth substrates were used as 20 or $10 \%$ ( $\mathrm{vol} / \mathrm{vol})$ solutions in water, sterilized by filtration, and added aseptically to ASW medium at a final concentration of $0.3 \%$ for methanol and fructose and $0.2 \%$ for other substrates, unless otherwise stated. Inocula were overnight cultures in ASW-methanol medium that were centrifuged and suspended in ASW. The volume of inoculum was calculated to obtain a starting absorbance at $600 \mathrm{~nm}$ of 0.05 (ca. $10^{8}$ cells per $\mathrm{ml}$ ). Growth with methylated amines was tested without $\mathrm{NH}_{4} \mathrm{Cl}$ in the medium. The methylated amines used were hydrochloride salts obtained from Sigma. Formic acid was used as a sodium salt provided by Sigma. All of the cultures were incubated at $30^{\circ} \mathrm{C}$ with shaking. Carbon source utilization tests were done with API-CH, API-AO, and API-AA strips (API System, La Balme-les-Grottes, France) (20) with the inocula described above. Growth on methane was tested in liquid cultures and on solid cultures incubated under an atmosphere containing 20\% methane and $80 \%$ air, and autotrophic growth was tested under an atmosphere containing $85 \% \mathrm{H}_{2}, 10 \% \mathrm{CO}_{2}$, and $5 \%$ oxygen.

Enrichments and isolations. For enrichment seawater medium was inoculated with pieces of red or green algae or with marine muds taken from zones exposed at low tide on the coasts of France and Iraq. Suspensions of muds $(5 \mathrm{~g}$ in $40 \mathrm{ml}$ of seawater) were centrifuged for $10 \mathrm{~min}$ at $200 \times \mathrm{g}$, and $6 \mathrm{ml}$ of each supernatant was filtered on Millipore membranes (pore size, $0.45 \mu \mathrm{m}$ ), which were then washed with sterile seawater before transfer in enrichment medium. When growth was visible (after 2 to 6 days at $30^{\circ} \mathrm{C}$ under slow agitation), the cultures were streaked onto the same medium. After several successive reisolations of single colonies, the presence of heterotrophic colonies was checked by spreading samples of a well-grown liquid culture in methanol medium onto plates of Difco nutrient agar containing $1 \%$ $\mathrm{NaCl}$ and plates of Difco marine agar 2216.

Electron microscopy. Bacterial cells grown in ASW-methanol or ASW-fructose medium were centrifuged and suspended in $100 \mathrm{mM}$ diethylbarbituric acid-sodium acetate buffer (pH 6.8) containing $2.5 \%$ glutaraldehyde (45). After 1 $\mathrm{h}$, the samples were concentrated in $2.5 \%$ agar $(55)$, postfixed overnight as described by Ryter and Kellenberger (45), dehydrated with acetone, and embedded in Epon. Thin sections were stained with lead citrate. Polysaccharides were revealed by two different methods, phosphotungstic acid staining and silver proteinate treatment. Phosphotungstic acid staining was achieved by using the method of Rambourg (37), as modified by Roland et al. (42), and was used after the procedure of Frehel and Ryter (19), which was slightly modified by extending to $20 \mathrm{~min}$ the phosphotungstic acid treatment, followed by thorough rinsing (twice for $10 \mathrm{~s}$ and twice for $10 \mathrm{~min}$ ). The detailed procedure of the silver proteinate treatment of Thiery (52) has been described previously (18). Phosphotungstic acid staining preferentially reveals peptidoglycan, and silver proteinate staining shows the polymers containing $\alpha$-glycol bonds, such as glycogen and teichoic acid $(18,44,52)$.

Estimation of lysis. A culture in ASW-methanol medium corresponding to 80 to $100 \mathrm{mg}$ (dry weight) of bacterial cells was centrifuged at $4^{\circ} \mathrm{C}$ during the early stationary phase. The pellet was suspended in $25 \mathrm{ml}$ of cold $0.5 \mathrm{M} \mathrm{NaCl}$, and the total protein content $(T)$ of this suspension was estimated by the Biuret method as modified for whole cells (23). This cell suspension was centrifuged at $12,000 \times g$ for $30 \mathrm{~min}$, and the pellet was suspended in $8 \mathrm{ml}$ of cold distilled water and was 
kept on ice for $1 \mathrm{~h}$. The lysed suspension was centrifuged at $12,000 \times g$ for $30 \mathrm{~min}$, and the protein contents in the residual pellet $(P)$ and the supernatant $(S)$ were estimated after concentration with trichloroacetic acid (final concentration, $12.5 \%$ ). The percentage of lysis was calculated as follows: $S / T \times 100$. We verified that $T=S+P$ and that the supernatant after $\mathrm{NaCl}$ treatment did not contain an appreciable amount of protein. The same procedure was applied to the following gram-negative methylotrophic strains: Pseudomonas sp. strain AM1 (35), Pseudomonas sp. strain M27 (3), Pseudomonas sp. strain C (40), and "Methylomonas methanolica" (1) cultivated in M3 medium (40) with methanol as the growth substrate; $P$. fluorescens CIP 7325 and $E$. coli $\mathrm{K}-12$ cultivated in mineral medium containing $0.2 \%$ glucose.

DNA studies. Bacterial DNA was prepared by the method of Brenner et al. (9). The method used to determine guanineplus-cytosine contents has been described previously (27). The procedures used for in vitro labeling of DNA with tritium-labeled nucleotides and for hybridization experiments (S1 nuclease-trichloroacetic acid method) were those of Grimont et al. (22). The temperature at which $50 \%$ of the reassociated DNA became hydrolyzable by $S 1$ nuclease $\left(T_{m}\right)$ was determined by the method of Crosa et al. (12). The value called $\Delta T_{m}$ was the difference between the $T_{m}$ of homologous reaction and the $T_{m}$ of the heterologous reaction. Such a value is an estimate of divergence between two DNAs (7).

Enzyme assays. For all assays except the methylamine dehydrogenase and methylglutamate dehydrogenase assays bacteria were grown in ASW-methanol medium; for the methylamine dehydrogenase and methylglutamate dehydrogenase assays methylamine was used as the growth substrate. Freshly harvested cells were suspended in cold 50 $\mathrm{mM}$ potassium phosphate buffer $(\mathrm{pH} 7.2)$, passed twice through a French pressure cell at $16,000 \mathrm{lb} / \mathrm{in}^{2}$, and centrifuged for $2 \mathrm{~h}$ at $200,000 \times \mathrm{g}$. The supernatant was used for all assays unless stated otherwise. Protein concentrations were determined by using Coomassie blue G-250 (47) and bovine serum albumin as the standard. Methanol dehydrogenase (EC.1.99.8) was assayed by the method of Anthony and Zatman (4) (modified by adding $10 \mathrm{mM} \mathrm{KCN}$ to the cuvette). Hexulose phosphate synthase was assayed by the method of Ferenci et al. (16), and hydroxypyruvate reductase (EC.1.1.1.49) was assayed as described by Large and Quayle (32). For glucose-6-phosphate dehydrogenase (EC 1.1.1.49), activity was followed at $340 \mathrm{~nm}$ in an assay mixture containing $25 \mu \mathrm{mol}$ of tris(hydroxymethyl)aminomethane hydrochloride $\left(\mathrm{pH} \mathrm{7.8)}, 5 \mu \mathrm{mol}\right.$ of $\mathrm{MgCl}_{2}, 10 \mu \mathrm{mol}$ of D-glucose 6-phosphate, and $2 \mu \mathrm{mol}$ of oxidized nicotinamide adenine dinucleotide in a total volume of $1 \mathrm{ml}$. The presence of nicotinamide adenine dinucleotide (NAD)-independent methylamine dehydrogenase (EC 1.4.99.3) was tested by the method of Eady and Large (15). Methylglutamate dehydrogenase (EC 1.5.99.5) was assayed by the method of Hersh et al. (24), using $N$-methyl-L-glutamate as the substrate. The addition of $2.5 \mathrm{mM} \mathrm{KCN}$ was often necessary to reveal the activity of this enzyme. Methylglutamate dehydrogenase was found in part in the supernatant and in part in the pellet in varying proportions depending on the extract. All of the enzymatic assays were performed at $28^{\circ} \mathrm{C}$. The specific activities were expressed as nanomoles of substrate consumed or of product formed per minute per milligram of protein.

Electrophoresis. Electrophoresis on $7.5 \%$ polyacrylamide gels was performed by the method of Laemmli (31), except that sodium dodecyl sulfate and mercaptoethanol were omit- ted and the crude extract samples were not heated. Bromophenol blue was used as the front marker. Electrophoresis was carried out at $4^{\circ} \mathrm{C}$ at a constant current of $25 \mathrm{~mA}$. After electrophoresis, dehydrogenases were revealed by treatment for $30 \mathrm{~min}$ at room temperature with the following mixtures (total volume, $50 \mathrm{ml}$ ): for glucose 6-phosphate dehydrogenase, a solution containing $50 \mathrm{mM}$ tris (hydroxymethyl)aminomethane hydrochloride ( $\mathrm{pH} 7.8$ ), $5 \mathrm{mM} \mathrm{MgCl}_{2}, 10 \mathrm{mM}$ glucose 6-phosphate (disodium salt; Sigma), $1 \mathrm{mM}$ NAD, 2 $\mathrm{mg}$ of phenazine methosulfate, and $20 \mathrm{mg}$ of Nitro Blue Tetrazolium; for 6-phosphogluconate dehydrogenase, a solution containing $50 \mathrm{mM}$ glycylglycine $(\mathrm{pH} 7.5), 5 \mathrm{mM}$ $\mathrm{MgCl}_{2}, 10 \mathrm{mM}$ 6-phosphogluconate (trisodium salt; Sigma), $1 \mathrm{mM}$ NAD, $2 \mathrm{mg}$ of phenazine methosulfate, and $20 \mathrm{mg}$ of Nitro Blue Tetrazolium; and for formate dehydrogenase, a solution containing $50 \mathrm{mM}$ tris(hydroxymethyl)aminomethane hydrochloride ( $\mathrm{pH} 8.4), 1 \mathrm{mM}$ NAD, $10 \mathrm{mM}$ sodium formate, $2 \mathrm{mg}$ of phenazine methosulfate, and $20 \mathrm{mg}$ of Nitro Blue Tetrazolium. The distance of migration of each enzyme was measured relative to the migration of the front marker $\left(R_{f}\right)$.

Controls without dehydrogenase substrates (NAD and glucose 6-phosphate, 6-phosphogluconate, or formate) were used to reveal the bands of "nothing dehydrogenases." Such bands (see Fig. 3) were identified as methanol dehydrogenases by the following procedure: after electrophoresis, a region of the gel which was supposed to contain the enzyme according to its $R_{f}$ value was cut out, and the piece of gel (ca. 6 by $3 \mathrm{~mm}$ ) was eluted at room temperature in a cuvette containing $2 \mathrm{ml}$ of $15 \mathrm{mM} \mathrm{NH} \mathrm{mCl}_{4}$ in $100 \mathrm{mM}$ tris (hydroxymethyl)aminomethane hydrochloride $(\mathrm{pH} 9)$. After $1 \mathrm{~h}$ the

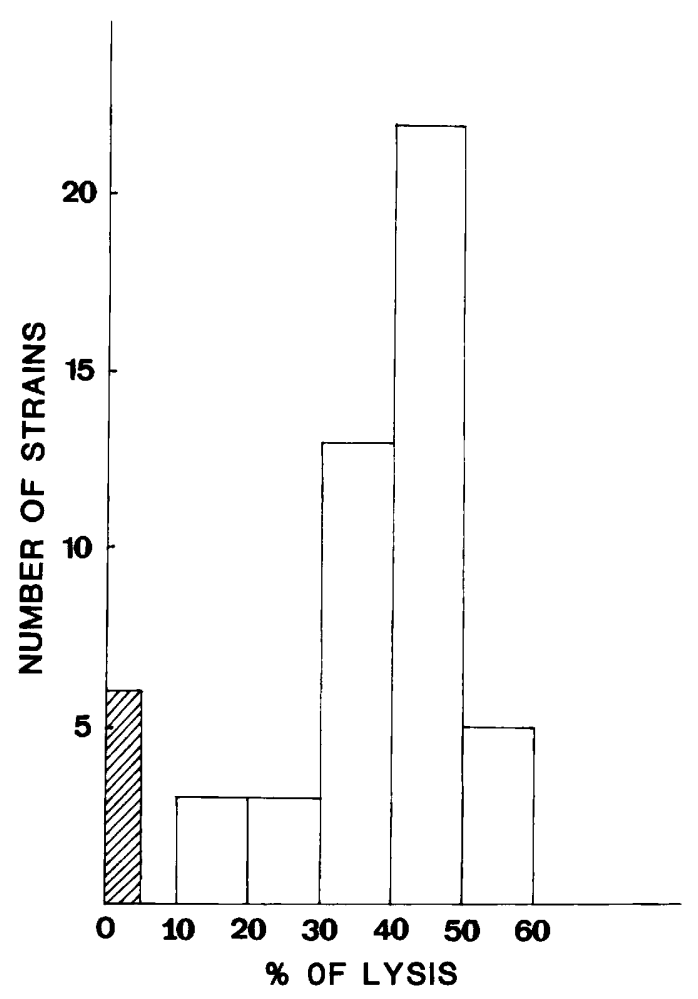

FIG. 1. Percentage of lysis of marine methylotrophic bacteria following osmotic shock. The protein contents were assayed in the supernatants and are expressed as percentages of the total cellular protein content. The cross-hatched bar indicates the results obtained with terrestrial strains used as controls (see text). 


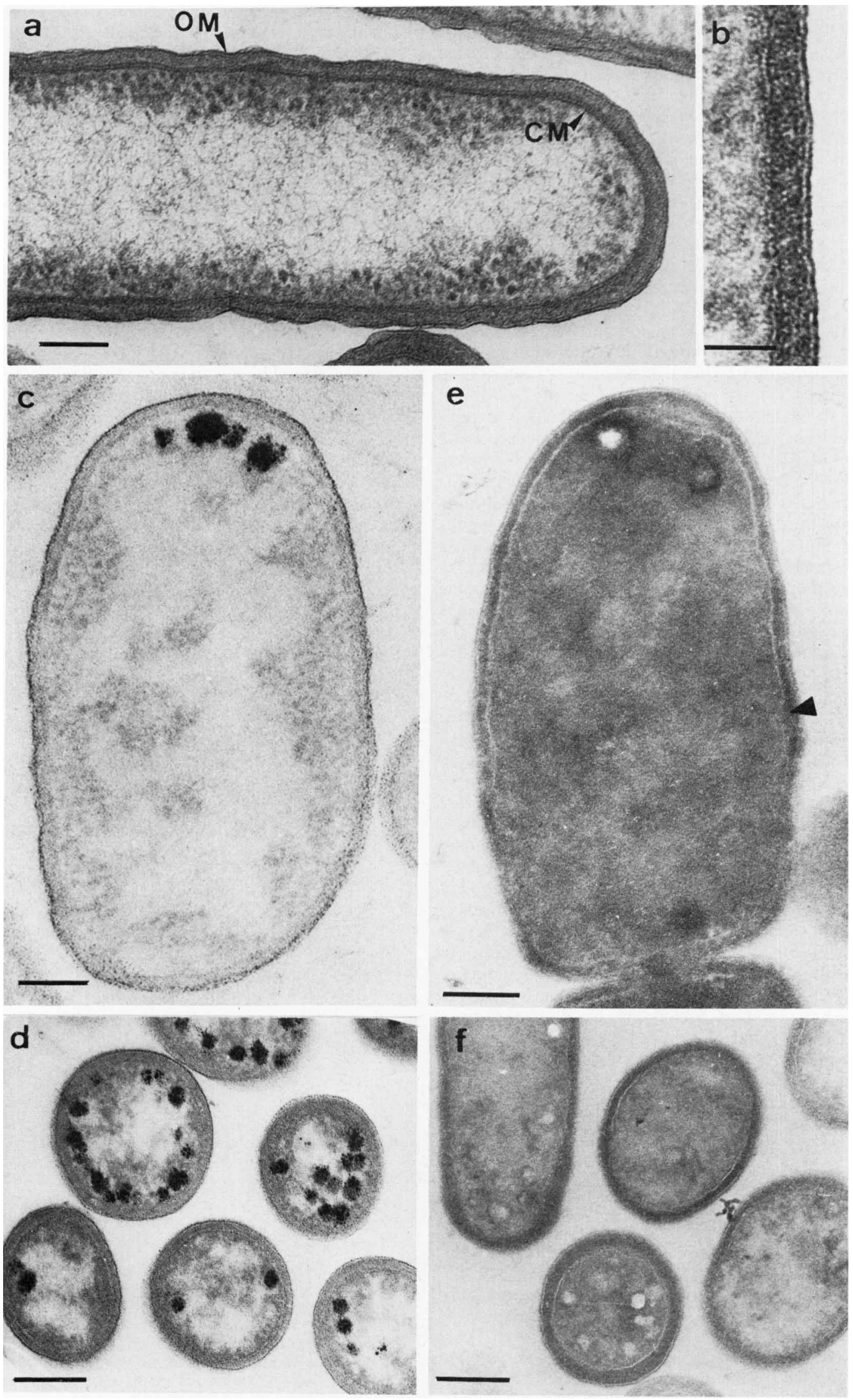


piece of gel was removed, and the methanol dehydrogenase assay was performed directly in the cuvette as described above.

\section{RESULTS}

Six samples of algae and 33 samples of marine mud were examined. All of the enrichment cultures gave visible growth in ASW-methanol medium after 3 to 6 days. On primary isolations, after 5 to 6 days of incubation, colonies of two different sizes were present; there were numerous punctiform colonies which were not viable after reisolation and larger, lightly pink-pigmented colonies (diameter, 0.5 to 2 $\mathrm{mm}$ ) of various morphological types, which became more uniform after reisolation. Eventually, 42 strains exhibiting good growth on seawater-methanol medium were kept for further examination.

General characteristics. All of the organisms isolated were gram-negative small rods (ca. 1 by $0.2 \mu \mathrm{m}$ ). Some of the isolates appeared coccoid in older (3- to 5-day) cultures. Under phase-contrast microscopy no cytoplasmic granules were observed. In ASW-methanol medium, all of the strains except two were motile by a single polar flagellum. The colonies were translucent, pale pink, and round with glossy surfaces and entire edges; they were 1 to $2 \mathrm{~mm}$ in diameter after 4 days at $30^{\circ} \mathrm{C}$ on solid ASW-methanol medium. No growth occurred on nutrient agar (Difco) supplemented with $10 \mathrm{~g}$ of $\mathrm{NaCl}$ per liter and on marine agar 2216 (Difco). The temperature range for growth extended from 10 to $40^{\circ} \mathrm{C}$, with optimal growth between 30 and $37^{\circ} \mathrm{C}$. All strains required vitamin $\mathrm{B}_{12}$ for growth, were strict aerobes, produced catalase, oxidase, and urease, and did not reduce nitrate. The guanine-plus-cytosine content was 38 to $46 \mathrm{~mol} \%$ (calculated for 33 strains).

Osmotic sensitivity and salt requirement. When transferred into distilled water after $\mathrm{NaCl}$ treatment, the cells of all of our marine isolates broke open and liberated their protein contents, as shown in Fig. 1. Terrestrial heterotrophic or methylotrophic bacteria of various types (RuMP or serine pathway) did not solubilize their protein contents after such an osmotic shock. The $\mathrm{NaCl}$ treatment was a necessary step before osmotic shock to obtain good lysis. Direct transfer of the cell pellet in distilled water and repeated washing in water did not produce appreciable lysis. The divalent cations $\mathrm{Mg}^{2+}$ and $\mathrm{Ca}^{2+}$ at concentrations as low as $50 \mathrm{mM}$ added to the $0.5 \mathrm{~m} \mathrm{NaCl}$ washing solution prevented lysis.

For all of the strains tested, optimal growth was obtained with minimum concentrations of $20 \mathrm{mM} \mathrm{Na}^{+}$and $5 \mathrm{mM}$ $\mathrm{Mg}^{2+}$ in otherwise normal ASW-methanol medium. This moderate halophily is comparable to the salt requirement of many marine bacteria (39).

Structural characteristics. The main morphological feature of thin sections (Fig. 2a and b) was the thickness (20 to 30 $\mathrm{nm}$ ) of the granular layer between the cytoplasmic and outer membranes. Such thickness is unusual for a gram-negative organism (11). This characteristic was observed in four different strains, whatever the nature of the growth substrate (methanol or fructose). A similar thickness of cell envelopes was observed by Rokem et al. (41) in terrestrial methylo- trophs which use the RuMP pathway. We have not observed the protrusions of the outer membrane reported by these authors in Pseudomonas sp. strain C.

Silver proteinate staining revealed a thin layer of polysaccharide along the outer face of the outside membrane (also lightly stained with phosphotungstic acid) and large clusters of glycogen-like material localized in the cytoplasm (Fig. 2c and $d$ ). The exact nature of this reserve material has not been determined. Peptidoglycan, as revealed by phosphotungstic acid, appeared as a weak dark brown deposit in the periplasmic layer (Fig. $2 \mathrm{e}$ and $\mathrm{f}$ ). A cell wall preparation of strain $92 \mathrm{~b}$ extracted and analyzed by $\mathrm{O}$. Kandler, Botanische Institut der Universität München, Munich, Federal Republic of Germany, confirmed the very low content of peptidoglycan observed by electron microscopy. The peptidoglycan contained meso-diaminopimelic acid and muramic acid together with alanine and glutamic acid. These findings fit with the assumption that strain $92 \mathrm{~b}$ contains the same murein as the other gram-negative organisms $(O$. Kandler, personal communication).

Nutritional and biochemical characteristics. None of the 42 isolates grew on glucose, acetate, ethanol, pyruvate, lactate, succinate, or citrate in ASW medium or in ASW medium supplemented with $0.1 \%$ tryptone and $0.1 \%$ yeast extract. A survey of 147 compounds, including amino acids, organic acids, sugars, and polyalcohols distributed in API-CH, APIAO, and API-AA strips, was conducted with two strains, strains $92 \mathrm{~b}$ and $222^{\mathrm{T}}$. This survey showed that fructose is the only non- $\mathrm{C}_{1}$ compound that is utilized by these strains. In fact, all of the strains (except two) utilized fructose as a sole carbon and energy source in ASW medium. However, depending on the strain, growth conditions, such as aeration and temperature, may be critical; some strains which failed to utilize fructose at $30^{\circ} \mathrm{C}$ in shaken culture were able to do so at room temperature without agitation.

Autotrophic growth was not observed. Methane (20\%) and formate $(0.1$ and $0.01 \%)$ did not support growth. Methylamine was a suitable carbon and nitrogen source for all of the strains. This compound was dissimilated either directly through an NAD-independent methylamine dehydrogenase or through the cycle which involves a methylglutamate dehydrogenase (24). Dimethylamine was utilized by 17 strains, and trimethylamine was utilized by 10 of the 42 new isolates. All of the strains which utilized trimethylamine also utilized dimethylamine. Details of these results for 11 strains are shown in Table 1.

Methanol dehydrogenase, hexulose phosphate synthase, and glucose-6-phosphate dehydrogenase were detected in crude extracts of the strains listed in Table 1. Hydroxypyruvate reductase activity was not found. Hexulose phosphate synthase, a key enzyme of the RuMP pathway, was present at a high specific activity; for example, 3,400 $U$ of hexulose phosphate synthase was detected in crude extracts of strain $92 \mathrm{~b}$, along with $728 \mathrm{U}$ of methanol dehydrogenase and $261 \mathrm{U}$ of glucose-6-phosphate dehydrogenase.

DNA-DNA hybridizations. For DNA-DNA hybridization experiments 14 strains were selected, including 3 strains described by Yamamoto et al. (58) and 11 of our isolates.

FIG. 2. Thin sections of strain 92b. ( $a$ and $b$ ) Lead citrate staining. The periplasmic space appears as a thick layer with a granular structure (detail in b) located between the outer membrane (OM) and the cytoplasmic membrane $(\mathrm{CM})$. (a) Bar $=0.1 \mu \mathrm{m}$. (b) Bar = $0.04 \mu \mathrm{m}$. (c and d) Silver proteinate staining. A thin, dark, granulated layer of polysaccharide overlays the whole cell surface. Clusters of glycogen-like material are present in the cytoplasm. (c) Bar $=0.1 \mu \mathrm{m}$. (d) Bar $=0.2 \mu \mathrm{m}$. (e and f) Phosphotungstic acid staining. The peptidoglycan was revealed by this treatment as a faintly stained layer (arrowhead) in the periplasmic space. (e) $\mathrm{Bar}=0.1 \mu \mathrm{m}$. (f) $\mathrm{Bar}=0.2 \mu \mathrm{m}$. 
TABLE 2. DNA reassociation among marine methylotrophic bacteria and reference strains

\begin{tabular}{|c|c|c|c|c|c|c|}
\hline \multirow{3}{*}{ Source of unlabeled DNA } & \multicolumn{6}{|c|}{ Source of labeled DNA } \\
\hline & \multicolumn{2}{|c|}{$\begin{array}{l}\text { "A. thalassomethanolica" } \\
\text { ATCC } 33145\end{array}$} & \multirow{2}{*}{$\begin{array}{c}\text { "Methylomonas } \\
\text { thalassica" ATCC } \\
331466^{\top}: \% \text { relative } \\
\text { binding }\end{array}$} & \multirow{2}{*}{$\begin{array}{c}\text { Strain } 222^{\mathrm{T}} \text { : } \\
\% \text { relative } \\
\text { binding }\end{array}$} & \multicolumn{2}{|c|}{ Strain $92 b$} \\
\hline & $\begin{array}{l}\text { \% Relative } \\
\text { binding }\end{array}$ & $\begin{array}{l}\Delta T_{m} \\
\left({ }^{\circ} \mathrm{C}\right)\end{array}$ & & & $\begin{array}{l}\text { \% Relative } \\
\text { binding }\end{array}$ & $\begin{array}{l}\Delta T_{m} \\
\left({ }^{\circ} \mathrm{C}\right)\end{array}$ \\
\hline \multicolumn{7}{|l|}{ Methylophaga thalassica } \\
\hline $\begin{array}{l}\text { "Alteromonas thalassomethanolica" } \\
\text { ATCC } 33145\end{array}$ & 100 & 0 & 61 & 31 & 26 & \\
\hline $\begin{array}{l}\text { "Methylomonas thalassica" ATCC } \\
33146^{\mathrm{T}}\end{array}$ & 66 & 6 & 100 & 32 & 29 & \\
\hline $\begin{array}{l}\text { "Methylomonas thalassica" NCMB } \\
2162\end{array}$ & 71 & 5.5 & 71 & 25 & 25 & \\
\hline New strain 310 & 74 & & 74 & 32 & 25 & \\
\hline New strain 150 & 70 & 5.9 & & 31 & 25 & \\
\hline New strain $2 b$ & 71 & & & 34 & 31 & \\
\hline New strain $1 d$ & 75 & & & 37 & 31 & \\
\hline \multicolumn{7}{|l|}{ Methylophaga marina } \\
\hline $222^{\mathrm{T}}$ & 36 & $>16$ & 31 & 100 & 94 & 0 \\
\hline $92 b$ & 21 & & 24 & 114 & 100 & 0 \\
\hline 81 & 25 & & & 81 & 84 & 1.29 \\
\hline 290 & 23 & & & 82 & 84 & \\
\hline 232 & 30 & & & 86 & 83 & 2.04 \\
\hline 312 & 32 & 10.7 & & 103 & 103 & \\
\hline 173 & 20 & & 33 & 86 & 85 & 2.17 \\
\hline Altermonas macleodii NCMB $1963^{\mathrm{T}}$ & 8 & & 1 & & 2 & \\
\hline $\begin{array}{l}\text { Methylobacillus glycogenes ATCC } \\
29475^{\mathrm{T}}\end{array}$ & 2 & & 1 & & 3 & \\
\hline $\begin{array}{l}\text { "Methylophilus methylotrophus" } \\
\text { NCIB } 10515\end{array}$ & 8 & & 6 & & 5 & \\
\hline
\end{tabular}

Two DNA hybridization groups were distinguished (Table 2 ). The first group contained the suggested type strain of " $A$. thalassomethanolica" and two strains of "Methylomonas thalassica," including the suggested type strain (strain ATCC 33146) (fructose positive) and strain 2162 (fructose negative). Four newly isolated strains also belonged to this group. Levels of DNA homology of 66 to $75 \%$ among the members of this group suggested some genetic diversity at the subspecific level. The $\Delta T_{m}$ values (less than $6^{\circ} \mathrm{C}$ ), confirmed that they belong to a single genospecies (7). A second hybridization group, composed of seven newly isolated strains, was more homogeneous based on their high levels of DNA hybridization.

The levels of DNA relatedness between the two groups (from 20 to $36 \%$ ) are compatible with their assignation to the same genus (8).

DNAs from representative marine strains belonging to the two hybridization groups mentioned above did not hybridize consistently with DNAs from two terrestrial strains, the type strain of Methylobacillus glycogenes and "Methylophilus methylotrophus" NCIB 10515. These two strains are representative of the two DNA hybridization groups described by Byrom (10).

Electrophoretic migration of enzymes. The data in Table 1 show that none of the phenotypic characters reported supports without exception the separation into two species obtained by DNA-DNA hybridization. The migration patterns of the dehydrogenases for glucose 6-phosphate, 6phosphogluconate, methanol, and formate were studied. Without substrate many bands of nothing dehydrogenases were revealed (Fig. 3A). The most intense bands $\left(R_{f}, 0.19\right.$ to 0.30 ) were identified as methanol dehydrogenases; in each hybridization group, two patterns of migration of this enzyme were recognized. Only the migration distances of the NAD-dependent glucose-6-phosphate dehydrogenases cor- related well with the hybridization groups; their $R_{f}$ values were 0.33 and 0.35 for the first and second hybridization groups, respectively (Fig. 3B). As for the NAD-dependent 6-phosphogluconate and formate dehydrogenases, the variations observed in the migration distances within each hybridization group did not allow any clear grouping.

\section{DISCUSSION}

The bacteria described by Yamamoto et al. (57), strain FMD of Strand and Listrom (49), and our strains were isolated from marine environments as diverse as the seashores of Japan, Norway, South California, Iraq, and France (English Channel and Atlantic Ocean). All are gram-negative rod-shaped obligate methylotrophs (except some which utilize fructose) that use the RuMP pathway and are unable to grow on methane. All of the strains which we examined belong to a single taxonomic group, as shown in Table 2 . Methylotrophic bacteria with the same characteristics are well known in terrestrial environments. We did not find in marine samples any of the gram-negative pink-pigmented facultative methylotrophs (21) which use the serine pathway and are so frequently found in terrestrial environments. Until now the only known marine methylotrophs which use the serine pathway belong to the genus Hyphomicrobium (5, 25).

The seacoast location where our samples were taken raises the question of the marine nature of these bacteria. An interesting property of marine bacteria is cell lysis in distilled water after $\mathrm{NaCl}$ treatment $(13,38)$. Rayman and MacLeod have shown that the sparse peptidoglycan of marine bacteria is strengthened by divalent cation bridges (38). The displacement of divalent cations by monovalent cations weakens the cell wall, making it sensitive to osmotic shock. This behavior toward osmotic shock is found only in marine bacteria, not 


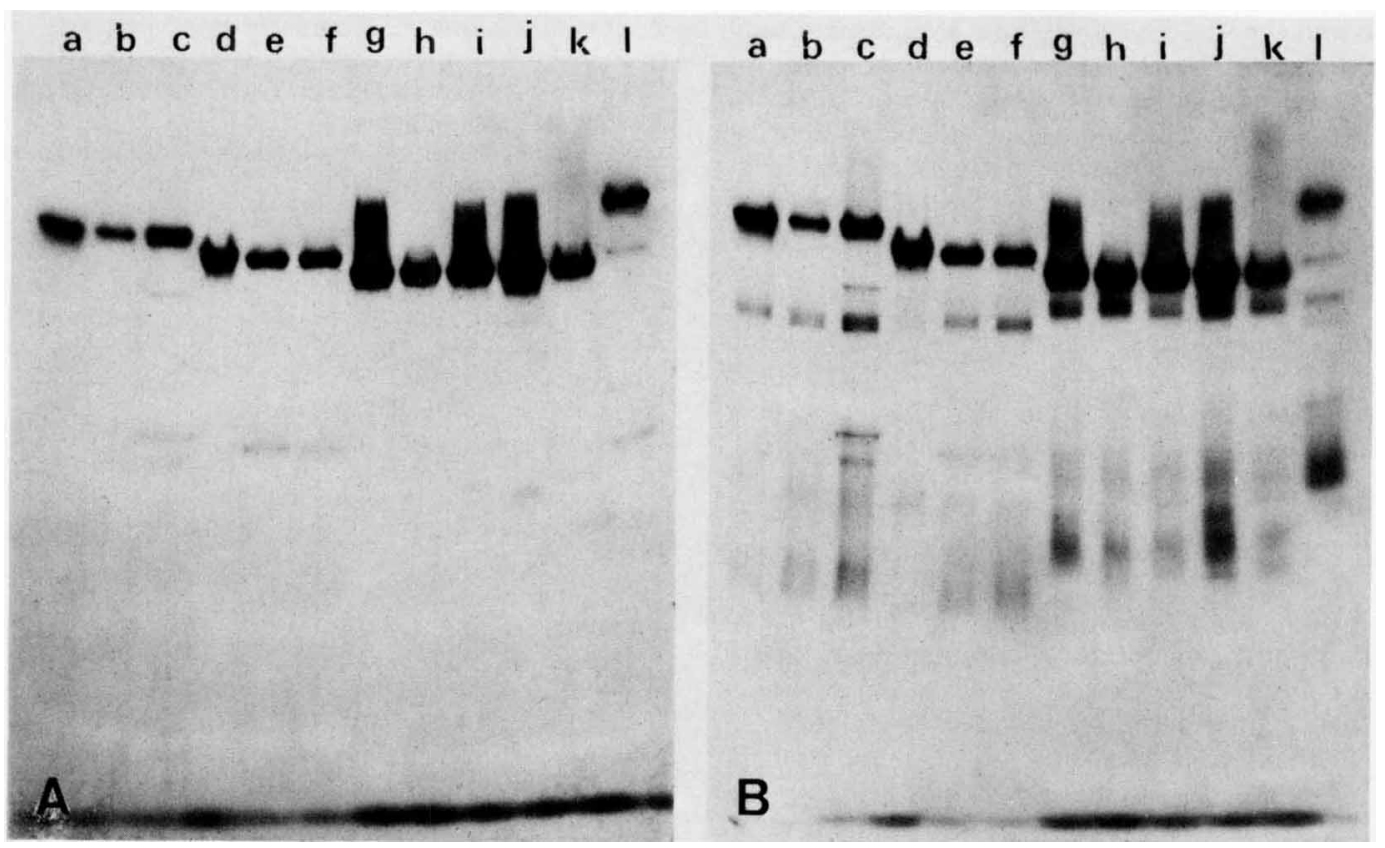

FIG. 3. Electrophoretic migration patterns of methanol dehydrogenases and glucose-6-phosphate dehydrogenases of marine methylotrophic bacteria. The lanes contained extracts of the strains. Lane a, Strain ATCC $33146^{\mathrm{T}}$; lane b, strain 310 ; lane c, strain 150 ; lane d, strain ATCC 33145; lane e, strain 2b; lane f, strain 1d; lane g, strain 290; lane h, strain 232; lane i, strain 312; lane j, strain 173; lane k, strain 222 ${ }^{\mathrm{T}}$; lane 1, strain 92b. Extracts of strains NCMB 2162 and 81 (data not shown) migrated like extracts of strains ATCC 33145 (lane d) and 222 (lane k), respectively. (A) Revelation achieved without glucose 6-phosphate and without NAD. The thick bands of nothing dehydrogenases were identified as methanol dehydrogenases (see text); their $R_{f}$ values were 0.22 (lanes a through $\mathrm{c}$ ), 0.27 (lanes $\mathrm{d}$ through $\mathrm{f}$ ), 0.30 (lanes $\mathrm{g}$ through k), and 0.19 (lane 1). No additional band appeared when methanol was added as a substrate to the revealing mixture. (B) Results with glucose 6-phosphate and NAD as the substrates. Numerous indistinct bands appeared in the lower half of the gel, and sharp bands with two distinct $\boldsymbol{R}_{f}$ values $(0.35$ [lanes a through f] and 0.33 [lanes $\mathrm{g}$ through 1]) were present in front of the methanol dehydrogenases. The results were identical when nicotinamide adenine dinucleotide phosphate was used instead of NAD. Omission of NAD or nicotinamide adenine dinucleotide phosphate resulted in the pattern obtained in $(A)$.

in terrestrial bacteria. The low peptidoglycan content, which was demonstrated by electron microscopy and by chemical estimation, is also consistent with the marine nature of our isolates (38).

The question raised by Strand and Listrom (49) about the taxonomic similarity of marine and terrestrial strains of gram-negative rods which use the RuMP pathway received a clear answer in our study (Table 2); no significant hybridization was detected between representative strains of the two groups.

In order to identify their isolates, Yamamoto et al. (57) considered the utilization of fructose a key character; they assigned the fructose-positive strains to a heterotrophic genus, Alteromonas, and the fructose-negative strains to "Methylomonas,"' which is considered a genus of strictly methylotrophic bacteria. This opinion has been criticized by Anthony (2), who remarked that the important point was that all of these bacteria are unable to grow on ordinary nutrient medium and so should be considered similar to obligate methylotrophs. Moreover, the ability to grow on fructose does not always give clear-cut results. Cultures of the type strain of "Methylomonas thalassica" received from the American Type Culture Collection (strain ATCC 33146) and from the National Collection of Industrial and Marine Bacteria (strain NCMB 2163) grew perfectly on fructose at $30^{\circ} \mathrm{C}$ in shaken cultures. This was confirmed by P. N. Green, National Collection of Industrial and Marine Bacteria (personal communication). Another strain of "Methylomonas thalassica" (strain NCMB 2162) failed repeatedly to grow on fructose; however, this strain belongs to the DNA-DNA hybridization group containing the suggested type strain of "A. thalassomethanolica."

The genus Alteromonas was created by Baumann et al. (6) as a group of gram-negative, heterotrophic, rod-shaped bacteria of marine origin. The lack of homology between $A$. macleodii (the type species of the genus Alteromonas) and "A. thalassomethanolica" was expected since Van Landschoot and De Ley (54) demonstrated that the latter species did not show any relatedness with any of the four DNAribosomal ribonucleic acid hybridization groups that they recognized among Alteromonas species.

The name Methylomonas was initially proposed by Foster and Davis (17) to replace "Methanomonas" in order to avoid confusion between methane-producing and methaneoxidizing microorganisms. Recently, Whittenbury and Krieg (56) assigned to the genus Methylomonas the strict methanotrophs that use the RuMP pathway and possess a type I intracellular membrane. Romanovskaya et al. (43) used the same definition for a formal description of genera and species of methane-utilizing bacteria. As a consequence, the name Methylomonas should not be used for those methylotrophic bacteria which do not have intracytoplasmic membranes and do not grow in methane. This view has been confirmed by the recent validation of the revived name Methylomonas (28).

Formal proposals for the creation of a new genus with two species (based on the data in Table 2) are given below. Nevertheless, the real taxonomic problem with the obligate methylotrophs, whatever their marine or terrestrial origins, is determination of relevant phenotypic characters that are 
easy to handle and correlate with genomic similarities (such as those detected by DNA-DNA hybridization). For this purpose, the relative electrophoretic migration distances of isofunctional enzymes have been used with success in other groups of bacteria (29). In terrestrial methylotrophic bacteria, results have been reported by Urakami and Komagata (53), but these results were not correlated with DNA hybridization studies. Figure 3 shows that for several enzymes, variable patterns of migration were found within each hybridization group. Such variations could be used for division at the subspecific level.

Description of Methylophaga gen. nov. Methylophaga gen. nov. (Me.thyl.o.pha'ga. French n. methyl, methyl radical; Gr. n. metha fermented beverage; Gr. n. hyle wood; Gr. v. phagein to eat; Methylophaga methyl eating) cells are gramnegative rods that are motile by means of single polar flagella. Very thick (20- to $30-\mathrm{nm})$ periplasmic space. Cells can be broken by osmotic shock after washing with $0.5 \mathrm{M}$ $\mathrm{NaCl}$. Strictly aerobic, moderately halophilic, and auxotrophic for vitamin $B_{12}$. Strains do not grow on peptoneyeast extract medium containing (or not containing) $\mathrm{NaCl}$. Except fructose, the only growth substrates that are used are $\mathrm{C}_{1}$ compounds, such as methanol and methylamine, which are dissimilated by the RuMP pathway. Do not grow on methane.

The range of guanine-plus-cytosine contents of the DNAs is 38 to $46 \mathrm{~mol} \%$.

Isolated from marine environments.

The type species is Methylophaga marina.

Description of Methylophaga marina sp. nov. Methylophaga marina sp. nov. (ma.ri'na. L. fem. n. mare sea; L. fem. adj. marina of the sea) cells are short straight rods 0.2 by $1 \mu \mathrm{m}$. Colonies on ASW-methanol agar are pale pink. Catalase and oxidase positive; reduction of nitrate negative. Optimum temperature, 30 to $37^{\circ} \mathrm{C}$. Grows at 10 and $40^{\circ} \mathrm{C}$. $\mathrm{Na}^{+}$and $\mathrm{Mg}^{2+}$ are required for growth. Grows on fructose and methylamine. Some strains grow on dimethylamine; none grows on trimethylamine. Methylamine is dissimilated by an $N$-methylamine dehydrogenase or through a methylglutamate dehydrogenase. On polyacrylamide gels, the electrophoretic migration distances relative to bromophenol blue ( $R_{f}$ values) are 0.33 for glucose-6-phosphate dehydrogenase and 0.30 or 0.19 for methanol dehydrogenase. The guanineplus-cytosine content of the DNA is 43 mol\%. The type strain is strain 222 ( = ATCC $35842=$ NCMB 2244).

Description of Methylophaga thalassica sp. nov. Methylophaga thalassica sp. nov. (tha.las'si.ca. Gr. adj. thalassica of the sea) cells are short straight rods 0.2 by $1 \mu \mathrm{m}$. Colonies on ASW-methanol agar are pale pink. Catalase and oxidase positive; reduction of nitrate negative. Optimum temperature, 30 to $37^{\circ} \mathrm{C}$. Grows at 10 and $40^{\circ} \mathrm{C}$. $\mathrm{Na}^{+}$and $\mathrm{Mg}^{2+}$ are required for growth.

Most strains grow on fructose and dimethylamine; some grow on trimethylamine. Most dissimilate methylamine through an $N$-methylglutamate dehydrogenase. The $R_{f}$ for glucose-6-phosphate dehydrogenase is 0.35 , and the $R_{f}$ for methanol dehydrogenase is 0.22 or 0.27 . The guanine-pluscytosine content of the DNA is $44 \mathrm{~mol} \%$. The level of hybridization with DNA of type species Methylophaga marina is around 30 to $35 \%$ ( $\mathrm{S} 1$ nuclease method).

The type strain is strain ATCC 33146 (= NCMB 2163).

\section{ACKNOWLEDGMENTS}

We thank Otto Kandler for performing the cell wall analysis, I. Goldberg for sending strains, and P. A. D. Grimont for interesting discussions during the course of this work and for revising the manuscript.

This research was supported by funds from Centre National de la Recherche Scientifique (grant ATP 1981), from Mission des Biotechnologies, Ministère de l'Industrie et de la Recherche, and from Université Paris 7.

\section{LITERATURE CITED}

1. Amano, Y., H. Sawada, N. Takada, and G. Terui. 1975. Isolation and characterization of Methylomonas methanolica nov. sp. J. Ferment. Technol. 53:315-326.

2. Anthony, C. 1982. The biochemistry of methylotrophs. Academic Press, Inc., London.

3. Anthony, C., and L. J. Zatman. 1964. The microbial oxidation of methanol. I. Isolation and properties of Pseudomonas sp. M27. Biochem. J. 92:609-613.

4. Anthony, C., and L. J. Zatman. 1967. The microbial oxidation of methanol. The prosthetic group of alcohol dehydrogenase of Pseudomonas sp. M27: a new oxidoreductase prosthetic group. Biochem. J. 104:960-969.

5. Attwood, M. M., and W. Harder. 1972. A rapid and specific enrichment procedure for Hyphomicrobium spp. Antonie van Leeuwenhoek J. Microbiol. Serol. 38:369-378.

6. Baumann, L., P. Baumann, M. Mandel, and R. D. Allen. 1972. Taxonomy of aerobic marine eubacteria. J. Bacteriol. 110: $402-429$.

7. Bonner, T. I., D. J. Brenner, B. R. Neufeld, and R. J. Britten. 1983. Reduction in the rate of DNA reassociation by sequence divergence. J. Mol. Biol. 81:123-135.

8. Brenner, D. J. 1978. Characterization and clinical identification of Enterobacteriaceae by DNA hybridization. Prog. Clin. Pathol. 7:71-117.

9. Brenner, D. J., A. C. McWhorter, J. K. Leete Knudson, and A. G. Steigerwalt. 1982. Escherichia vulneris: a new species of Enterobacteriaceae associated with human wounds. J. Clin. Microbiol. 15:1133-1140.

10. Byrom, D. 1980. Taxonomy of methylotrophs: a reappraisal, p. 279-284. In H. Dalton (ed.), Microbial growth on C1 compounds. Proceedings of the 3rd International Symposium on Microbial Growth on $\mathrm{C} 1$ Compounds. Heyden, London.

11. Costerton, J. W., J. M. Ingram, and K. J. Chenig. 1974. Structure and function of the cell envelope of gram-negative bacteria. Bacteriol. Rev. 38:87-110.

12. Crosa, J. H., D. J. Brenner, and S. Falkow. 1973. Use of a single-strand-specific nuclease for analysis of bacterial deoxyribonucleic acid homo- and heteroduplexes. J. Bacteriol. 115:904-911.

13. De Voe, I. W., and E. L. Oginsky. 1969. Antagonistic effect of monovalent cations in maintenance of cellular integrity of a marine bacterium. J. Bacteriol. 98:1355-1367.

14. Dostälek, M., and N. Molin. 1975. Studies of biomass production of methanol oxidizing bacteria, p. 385-401. In S. R. Tannenbaum and D. I. C. Wang (ed.), Single cell protein II. The MIT Press, Cambridge, Mass.

15. Eady, R. R., and P. J. Large. 1968. Purification and properties of an amine dehydrogenase from Pseudomonas AM1 and its role in growth of methylamine. Biochem. J. 106:245-255.

16. Ferenci, T., T. Strøm, and J. R. Quayle. 1974. Purification and properties of 3-hexulose phosphate synthase and phospho-3hexuloisomerase from Methylococcus capsulatus. Biochem. J. 144:477-486.

17. Foster, J. W., and R. H. Davis. 1966. A methane-dependent coccus, with notes on classification and nomenclature of obligate methane-utilizing bacteria. J. Bacteriol. 91:1924-1931.

18. Frehel, C., P. Robbe, R. Tinelli, and A. Ryter. 1982. Relationship between biochemical and cytochemical results obtained on Bacillus megaterium and Bacillus subtilis cell-wall polysaccharides. J. Ultrastruct. Res. 81:78-87.

19. Frehel, C., and A. Ryter. 1982. Electron microscopic cytochemical study of cell-wall polysaccharides in Bacillus subtilis and two strains of Bacillus megaterium. J. Ultrastruct. Res. 81:66-77.

20. Gavini, F., D. Izard, H. Leclerc, M. Desmonceaux, and J. P. 
Gayral. 1980. Carbon source assimilation test: comparison between a conventional method and a microtechnic (API) in study of Enterobacteriaceae. Zentralbl. Bakteriol. Parasitenkd. Infektionskr. Hyg. Abt. 1 Orig. Reihe C 1:182-187.

21. Green, P. N., and I. J. Bousfield. 1982. A taxonomic study of some gram-negative facultatively methylotrophic bacteria. J. Gen. Microbiol. 128:623-638.

22. Grimont, P. A. D., F. Grimont, J. J. Farmer III, and M. A. Asbury. 1981. Cedecea davisae gen. nov., sp. nov. and Cedecea lapagei sp. nov., new Enterobacteriaceae from clinical specimens. Int. J. Syst. Bacteriol. 31:317-326.

23. Herbert, D., P. J. Phipps, and R. E. Strange. 1971. Chemical analysis in microbial cells, p. 209-344. In J. R. Norris and D. W. Ribbons (ed.), Methods in microbiology, vol. 5B. Academic Press, Inc., London.

24. Hersh, L. B., J. A. Peterson, and A. A. Thompson. 1971. An N-methylglutamate dehydrogenase from Pseudomonas MA. Arch. Biochem. Biophys. 145:115-120.

25. Hirsch, P. 1974. Budding bacteria. Annu. Rev. Microbiol. 28:391-444.

26. Hohnloser, W., F. Lingens, and P. Präve. 1978. Characterization of a new methylotrophic strain, Methylomonas clara. Eur. J. Appl. Microbiol. 6:167-179.

27. Hontebeyrie, M., and F. Gasser. 1977. Deoxyribonucleic acid homologies in the genus Leuconostoc. Int. J. Syst. Bacteriol. 27:9-14.

28. International Journal of Systematic Bacteriology. 1984. Validation of the publication of new names and new combinations previously effectively published outside the IJSB. List no. 15. Int. J. Syst. Bacteriol. 34:355-356.

29. Johnson, J. L., C. F. Phelps, C. S. Cummins, J. London, and F. Gasser. 1980. Taxonomy of the Lactobacillus acidophilus group. Int. J. Syst. Bacteriol. 30:53-68.

30. Kouno, K., T. Oki, H. Nomura, and A. Ozaki. 1973. Isolation of a new methanol-utilizing bacteria and its thiamine requirement for growth. J. Gen. Appl. Microbiol. 19:11-21.

31. Laemmli, U. K. 1970. Cleavage of structural proteins during the assembly of the head of bacteriophage T4. Nature (London) 227:680-685.

32. Large, P. J., and J. R. Quayle. 1963. Microbial growth on C1 compounds. V. Enzyme activities in extracts of Pseudomonas AM1. Biochem. J. 87:386-396.

33. Loginova, N. V., and Y. A. Trotsenko. 1981. Characteristics of the obligate methylotroph Methylophilus methanolovorus. Microbiology (USSR) 50:13-18. (Translated from Russian.)

34. Ogata, K., Y. Izumi, M. Kawamori, Y. Asano, and Y. Tani. 1977. Amino acid formation by methanol utilizing bacteria. J. Ferment. Technol. 55:444-451.

35. Peel, D., and J. R. Quayle. 1961. Microbial growth on C1 compounds. I. Isolation and characterization of Pseudomonas AM1. Biochem. J. 81:465-469.

36. Pfennig, N. 1965. Anreicherungkulturen für rote und grüne Schwefelbakterien. Zentralbl. Bakteriol. Parasitenkd. Infektionsk. Hyg. Abt. 1 Suppl. 1:179-189.

37. Rambourg, A. 1969. Localisation ultrastructurale et nature du matériel coloré au niveau de la surface cellulaire par le mélange chromique phosphotungstique. J. Microsc. (Paris) 8:325-342.

38. Rayman, M. K., and R. A. MacLeod. 1975. Interaction of $\mathrm{Mg}^{2+}$ with peptidoglycan and its relation to the prevention of lysis of a marine pseudomonad. J. Bacteriol. 122:650-659.

39. Reichelt, J. L., and P. Baumann. 1974. Effect of sodium chloride on growth of heterotrophic marine bacteria. Arch. Microbiol. 97:329-345.

40. Rock, J. S., I. Goldberg, A. Ben-Bassat, and R. I. Mateles. 1976. Isolation and characterization of two methanol utilizing bacteria. Agric. Biol. Chem. 40:2129-2135.

41. Rokem, J. S., J. Reichler, and I. Goldberg. 1978. Electron microscopy of methanol-utilizing bacteria. Antonie van Leeuwenhoek J. Microbiol. Serol. 44:123-127.

42. Roland, J. C., C. A. Lembi, and D. J. Horre. 1972. Phosphotungstic acid-chromic acid as a selective electron dense stain for plasma membranes of plant cells. Stain Technol. 47:195-200.

43. Romanovskaya, V. A., Y. R. Malashenko, and V. N. Bogachenko. 1978. Corrected diagnosis of the genera and species of methane-utilizing bacteria. Microbiology (USSR) 47:96-103. (Translated from Russian.)

44. Rousseau, M., and J. Hermier. 1975. Localisation en microscopie électronique des polysaccharides de la paroi chez les bactéries en sporulation. J. Microsc. Biol. Cell. 23:237-248.

45. Ryter, A., and E. Kellenberger. 1958. Etude en microscope électronique de plasma contenant de l'acide désoxyribonucléique. I. Les nucléotides des bactéries en croissance active. $Z$. Naturforsch. 13:597-605.

46. Sahm, H., and F. Wagner. 1975. Isolation and characterization of an obligate methanol-utilizing bacterium, Methylomonas M15. Eur. J. Appl. Microbiol. 2:147-158.

47. Sedmak, J. J., and S. E. Grossberg. 1977. A rapid, sensitive, and versatile assay for protein using Coomassie brilliant blue G250. Anal. Biochem. 79:544-552.

48. Skerman, V. B. D., V. McGowan, and P. H. A. Sneath. 1980. Approved lists of bacterial names. Int. J. Syst. Bacteriol. 30:225-420.

49. Strand, S. E., and M. E. Listrom. 1984. Circracterization of a new marine methylotroph. FEMS Microbic.. Lett. 21:247-251.

50. Suzuki, M., I. Kühn, A. Berglund, A. Unden, and C. G. Heden. 1977. Identification of a new methanol-utilizing bacterium and its characteristic responses to some chemicals. J. Ferment. Technol. 55:459-465.

51. Taylor, I. J. 1977. Carbon assimilation and oxidation by Methylophilus methylotrophus-the ICI SCP organism, p. 52-54. In G. K. Skryabin, M. V. Ivanov, E. N. Kondratjeva, G. A. Zavarzin, Y. Trotsenko, and A. I. Nesterov (ed.), Microbia! growth on $\mathrm{C} 1$ compounds. Proceedings of the 2 nd International Symposium on Microbial Growth on $\mathrm{C} 1$ Compounds. USSR Academy of Sciences, Moscow.

52. Thiery, J. P. 1967. Mise en évidence des polysaccharides sur coupes fines en microscopie électronique. J. Microsc. (Paris) 6:987-1018.

53. Urakami, T., and K. Komagata. 1981. Electrophoretic comparison of enzymes in the gram-negative methanol utilizing bacteria. J. Gen. Appl. Microbiol. 27:381-403.

54. Van Landschoot, A., and J. De Ley. 1983. Intra- and intergeneric similarities of the rRNA cistrons of Alteromonas, Marinomonas (gen. nov.) and some other gram-negative bacteria. J. Gen. Microbiol. 129:3057-3074.

55. Whitehouse, R. L. S., J. C. Benichou, and A. Ryter. 1977. Procedure for the longitudinal orientation of rod shaped bacteria and production of high cell density of procaryotic and eucaryotic cells in thin sections for electron microscopy. Biol. Cell. 30:155-158.

56. Whittenbury, R., and N. R. Krieg. 1984. Genus II, Methylomonas (ex Leadbetter 1974) nom. rev., p. 260. In N. R. Krieg and J. G. Holt (ed.), Bergey's manual of systematic bacteriology. The Williams \& Wilkins Co., Baltimore.

57. Yamamoto, M., H. Iwaki, K. Kouno, and T. Inui. 1980. Identification of marine methanol-utilizing bacteria. J. Ferment. Technol. 58:99-106.

58. Yamamoto, M., Y. Seriu, K. Kouno, R. Okamoto, and T. Inui. 1978. Isolation and characterization of marine methanol-utilizing bacteria. J. Ferment. Technol. 56:451-458.

59. Yordy, J. R., and T. L. Weaver. 1977. Methylobacillus: a new genus of obligately methylotrophic bacteria. Int. J. Syst. Bacteriol. 27:247-255. 